\title{
PEMBINAAN NILAI-NILAI KARAKTER ANAK BERBASIS AI-QUR'AN SURAH AL-FATIHAH SEBAGAI PENGUATAN KARAKTER
}

\author{
Abd. Salam \\ STIT Sunan Giri Bima \\ Email: abdusalamstit@gmail.com
}

\begin{abstract}
The development of character values is currently experiencing a crisis of noble character, in facing a character crisis like this, it is necessary to develop Al-Fatihah-based character both in religious development, children's social spirit and character values as strengthening children's character. The development of character values is very important in order to keep children from being uncivilized to being civilized. The character values of Al-Fatihah in this study are as follows: Religious values, Integrity Values, Nationalist Values and Independent Values and Mutual Cooperation Values. If the character building is carried out, it will give birth to civilized children and their character will grow in carrying out their religious teachings. This study aims to examine 1.) Children's Character Development Based on the Qur'an Surah Al-Fatihah as Character Strengthening. 2.) Fostering children's character values in Al-Fatihah verses 1 to 7.
\end{abstract}

\begin{abstract}
ABSTRAK
Pembinaan nilai-nilai karakter saat ini sedang mengalami kiris karakter mulia, dalam menghadapi krisis karakter seperti ini diperlukan pembinaan-pembinaan karakter berbasis Al-Fatihah baik pada pembinaan Religius, jiwa sosial anak serta Pembinaan nilai-nilai karakter sebagai penguatan karakter anak. Pembinaan nilai karakter ini sangat penting dilakukan demi menjaga anak dari yang tidak beradab menjadi beradab. Nilai-nilai karakter pada Al-Fatihah dalam penelitian ini sebagai berikut: Nilai agama, Nilai Integritas, Nilai Nasionalis dan Nilai Mandiri serta Nilai Gotong Royong. Apabila dilakukan pembinaan karakter tersebut, maka akan melahirkan anak-anak yang beradab dan akan tumbuh karakternya dalam melaksanakan ajaran agamanya. Penelitian ini bertujuan untuk mengkaji 1.) Pembinaan Karakter anak Berbasis Al-Qur'an Surah AlFatihah Sebagai Penguatan Karakter. 2.) Pembinaan Nilai-nilai karakter anak pada AlFatihah ayat 1 sampai ayat 7.
\end{abstract}

Kata kunci : Pembinaan, Nilai-nilai Karakter, Al-Fatihah, penguatan karakter. 


\section{PENDAHULUAN}

Pembinaan karakter berbasis Al-Fatihah sangat penting dilakukan karena adab anak pada akhir-akhir ini semakin tidak berkarakter baik terhadap orang tuanya, keluarga, masyarakat, dan guru, dosen, serta pada orang lebih tua banyak diperbincangkan di kalangan masyarakat Indonesia, hingga di kalangan akademisi. Masyarakat Indonesia yang dulu sangat mencerminkan adab dan prilaku sopan santun terhadap sesama. Namun, sekarang lebih cenderung tidak beradab pada diri sendiri maupun pada orang lain, terutama karater anak sebagai penerus bangsa Indonesia saat ini sangat buruk dan tidak beradab. Kendati demikian, diperlukan pembinaan karakter berbasis Al-Fatihah.

Anas Salahudin dan Irwanto Alkrienciehie, mengatakan dalam buku Pendidikan Karakter, Pendidikan berbasis Agama dan Budaya Bangsa Menurut ajaran Islam, hakikat pendidikan adalah mengembalikan nilai-nilai ilahiah pada manusia (fitrah)dengan bimbingan Al-Qur'an dan As-Sunnah (hadits) sehingga menjadi manusia yang berakhlak mulia (insan kamil). ${ }^{1}$

Berdasarkan hal tersebut di atas, maka perlu dilakukan pembinaan karakter pada anak dengan tujuan menjadikan anak beradab sopan dan santun dalam berucap dan berbuat. Pembinaan karakter juga harus dilakukan terus-menrus agar adab (karakter) anak dapat tertanam pada jiwa anak sehingan dapat membentuk anak yang memiliki nilai-nilai karakter dalam kehidupanya sehari-hari. Proses pembinaan karakter berupaya mewujudkan nilai-nilai adab baik dalam berucap, berbuat sehingga nantinya anak akan hati-kehatian dalam menjaga karakter baik agat tidak dikotori karakter yang buruk. Proses pembinaan yang dilakukan butuh kesabaran dan keuletan dalam membina anak menjadi beradab. Pembinaan karakter setiap manusia menumbuhkan pertumbuhan yang baik sehingga pertumbuhan tersebut selalu terjaga baik dalam pertumbuhan jasmani dan rohaniah. Jasmani dan rohani sangat membutuhkan pembangunan yang harmonis, berdedikasi dalam menjaga tata tertib. ${ }^{2}$

\section{HASIL DAN PEMBAHASAN}

\section{Karakter}

Secara bahasa karakter merupakan adab prilaku sopan santun dalam berucap dan berbuat.

Secara istilah karakter merupakan sikap dan brilaku yang mencerminkan karakter mulia. Karakter menurut beberapa ahli yakni:

\footnotetext{
${ }^{1}$ Irwanto Alkrienciehie, Anas Salahudin, Pendidikan Karakter, Pendidikan Berbasis Agama dan Budaya Bangsa, Bandung Pustaka Setia, 2013, 49.
}

${ }^{2}$ Suparlan Suryapratondo, Ilmu Jiwa Kepribadian, (Jakarta : PT. Paryu Berkah, 1984), 116. 
1. Ryan; karakter berasal dari bahasa Yunani (Greek), yaitu charassein yang berarti "to engrave" mengukir.. ${ }^{3}$

2. Echols; Karakter diartikan dengan sikap seseorang pada orang lain yang memiliki budi pekerti luhur terhadap sesama, teutama pada dirinya sendiri, orang lain maupun masyarakat. ${ }^{4}$

3. Koesoema; Karakter yakni tabiat manusia yang memiliki prilaku terpuji dan tercela serta kepribadian yang diekspresikan dalam kehidupan sehari-hari baik dilingkungan masyarakat maupun dilingkungan akademisi. Sehingga sifat tersebut merupakan bawaan ia kecil hingga ia dewasa. dari perilaku bawaan sesuai dengan kondisi yang berbeda-beda dimana ia tinggal dan tentu memiliki nilai tersendiri dalam kehidupanya. ${ }^{5}$

Seusia apa yang disampaikan oleh para ahli di atas, bahwa karakter identik dengan akhlak, sikap sopan santun, perkataan yang tidak menyinggung orang lain, dan perbuatan tersebut didasari ilmu dan agama, sehingga yang dulu adalah akhlak, kemudian dirubah lagi menjadi etika, dan yang sekarang adalah karakter.

\section{Al-Qur'an (Al-Fatihah)}

Al-Qur'an (Al-Fatihah) merupakan induknya, sebagai pembuka dari segala macam bacaan (surah). Al-Fatihah asal kata fataha, yaftahu, fathan yakni sebagai pembukaan bacaan dalam meraih jalan kemenangan (surga). Sedangkan fatihah dalam arti kemenangan. Kata fath yang merupakan akar kata nama ini berarti menyingkirkan sesuatu yang terdapat pada suatu tempat yang akan dimasuki.

secara harfiah Al-Fatihah merupakan penamaannya karena ia terletak pada awal surah dan biasanya yang pertama memasuki sesuatu adalah yang embukanya, kata Fatihah di sini berarti awal atau surah pembuka dari segala surah yang ada dalam Al-Qur'an. ${ }^{6}$

Jadi Al-Fatihah merupakan surah pembuka dari segala surah, kunci dari setiap ayat baik ayat 1 hingga ayat 7 memiliki nilai-nilai karakter yang berbeda.

\footnotetext{
${ }^{3}$ John M. Dan Hassan Shadily, Echolis, Kamus Inggris Indonesia.Jakarta: Gramedia. Cet. X, 1987, 214.

${ }^{4}$ Pusat Bahasa Departemen Pendidikan Nasional, Kamus Bahasa Indonesia. Jakarta: Pusat Bahasa. Cet. I, 2008,682 .

${ }^{5}$ Doni Koesoema A, Pendidikan Karakter: Strategi Mendidik Anak di Zaman Global. Jakarta: Grasindo. Cet. I. 2007,80 .

${ }^{6}$ Abu Ubaidah, Darwis, Tafsir Al-Asas (Jakarta: Pustaka al-Kautsar, 2012), 20-23.
} 


\section{Penguatan Nilai-nilai Karakter pada anak berbasis Al-Qur'an}

Penguatan nilai karakter diperlukan pembinaan baik dalam nilai agama, integritas, mandiri, dan mandiri serta gotong royong. Pembinaan tersebut dilakukan secara intens agar nilai-nilai yang terkandung dalam Al-Fatihah tersebut dapat diamalkan dalam kehidupan seharihari. Jadi karakter merupakan kepribadian, perilaku yang mencerminkan nilai-nilai Islam.

Sesuai firman Allah SWT yang artinya: Sesungguhnya Engkau Muhammad lahir di di dunia dengan berbudi pekerti yang agung. (QS. Al-Qalam:4).

Uraian ayat di atas, bahwa karakter yang memiliki nilai-nilai agama maka tentu mengarahkan, membimbing, mendorong, membangun. Adapun susunan karakter yakni: jujur, tanggung jawab, tidak congkak, tidak sombong, adil, wara, toleransi, disiplin dan mandiri, religius, peduli terhadap seama, lingkungan, sosial, serta bertanggung jawab. Dalam surah AlFatihah Tuhan pencipta alam semesta (Allah) memerintahkan kepada seluruh manusia untuk mengerjakan amal sholeh, serta beriman semata-mata karena Allah SWT, seperti firman Allah yang artinya: "Sesungguhnya orang-orang yang beriman dan mengerjakan amal-amal saleh, mereka diberi petunjuk oleh Tuhan mereka karena keimanannya. (QS. Yunus: 9)”.

Uraian ayat di atas, bahwa Tuhan Yang Maha Esa (Allah SWT) menyeru dari segala macam perbuatan yang baik dan meninggalkan dari segala keburukan. Hingga jangan campur adukan mana yang haq dan mana yang bathil. Karena sesungguhnya perbuatan yang baik dapat mencegah dari perbuatan yang buruk. Oleh karena itu, semua perintah yang baik implementasikan dalam kehidupan sehari-hari, sehingga dapat bermanfaat untuk dirinya sendiri, orang lain. Jadi karakter yang sejati berdasarkan Al-Fatihah yakni menuntun manusia untuk beriman, cinta kebaikan, mengetahui kebenaran dan mampu mengamalkannya dalam kehidupan sehari-hari.

\section{Pembinaan Karakter Anak Berbasis Al-Fatihah}

Pembinaan karakter anak dalam Al-Qur'an surah Al-Fatihah pada awalnya memberikan pemahaman pada anak baik tutur kata, sopan santun, ini tidak cukup hanya satu kali akan tetapi berulang kali dan terus-menerus dilakukan. Sehingga anak tidak hanya mendengar di situ saja akan tetapi kemanapun anak pergi akan selalu mengingatnya. Namun, dibalik itu anak memerlukan pembinaan yakni:

Pembinaan yang menumbuh kembangkan karakter anak yakni:

1. Pembinaan Aqidah/Tauhid 
Pembinaan aqidah pada anak sangat penting dilakukan, karena anak memerlukan keyakinan yang benar dalam melahirkan buah keimanan, kepercayaan serta segala bentuk amaliyah.

Aqidah merupakan landasan keimanan yang tumbuh dari jiwa manusia yang beriman dan mengamalkan dalam kehiduapan sehari-hari. Aqidah tidak hanya di rasa, akan tetapi dikerjakan dalam bentuk perbuatan.

Aqidah merupakan pondasi utama dan pertama dalam ajaran Islam dan diperlukan pembinaan aqidah pada diri anak sehingga anak dapat mengenal aqidah yang sesuai AlQur'an dan Hadits, ijma' dan qiyas.

Sebagaimana firman Allah SWT yang artinya;

"Dan Luqman mengingatkan kepada anaknya dan berkata; wahai anaku, janganlah kamu mempersekutukan (Allah) sesungguhnya mempersekutukan (Allah) adalah benarbenar kezaliman yang besar". (QS. Luqman: 13).

Uraian ayat di atas, bahwa pembinaan aqidah pada anak dilakukan terus-menerus sampai aqidah tersebut tetanam pada jiwa anak sehingga anak dapat mengamalkan aqidah yang baik dan memiliki karakter yang mulia.

Penguatan aqidah dapat diperkuat oleh ilmu tasawuf antara lain:

1. Ilmu yaqin

Ilmu yaqin merupakan ilmu yang berdasarkan bukti (argumen atau dalil) sehingga dapat diterima oleh akal pikiran.

2. Ainul yaqin

Ainul yaqin merupakan ilmu yang adanya bukti hukum atau penjelasan.

3. Haqqul yaqin

Haqqul yaqin adalah ilmu yang adanya cahaya atau sifat terang.

Dengan adanya ketiga ilmu di atas, maka penguatan aqidah akan semakin kuat danL semakin menumbuhkan karakter anak. Akan tetapi tampa dibekali anak ketiga ilmu di atas baik itu ilmu yaqin, ainul yaqin, haqqul yakni, maka akan sia-sia dalam menumbuhkan karakter serta aqidah anak.

\section{Pembinaan Syari'at}

Pembinaan syariat sangat penting dalam kehidupan anak karena dengan syariat merupkana perbuatan yang dilakukan secara lahiriyah dan dijaga dan dirawat agar tidak tercampur aduk dengan hal yang bertentangan agama.

${ }^{7}$ T.M. Hasby Ash Shiddiqy, Sejarah dan Pengantar Ilmu Tauhid/Kalam, (Cet. VI ; Jakarta : PT. Bulan Bintang, 1992), 43. 
Syariat merupaka aturan dan tatacara dalam Islam yang di implementasikan dalam kehidupan sehari-hari dengan wujud perbuatan yang terlihat dengan mata kepala.

Syariat merupakan aturan dalam agama Islam sebagai pegangan hidup dengan sikap dan prilaku sopan santun dan tentu tidak bertentangan dari Al-Qur'an dan Hadits sehingga manusia dapat meningkatkan perbuatan amaliyahnya dalam mencapai kebahagiaan yang hakiki. ${ }^{8}$

Sebagaimana Allah SWT berfirman yang artinya:

"Kemudian Kami jadikan engkau (Muhammad) mengikuti syariat (peraturan) dari (agama) itu, maka ikutilah (syariat itu) dan janganlah engkau ikuti keinginan orangorang yang tidak mengetahui”'. (QS. Jatsiyah:18).

Penjelasan ayat di atas, bahwa kehidupan anak di dunia harus dibina secara benar dan baik dengan aturan, hukum dan norma-norma agama Islam yang tidak bertentangan dengan Al-Qur'an dan Hadits karena pembinaan syariat pada anak sebagai kunci kesadaran untuk bertutur kata sopan dan santun dan berprilaku baik pada diri sendiri maupun pada orang lain.

3. Pembinaan karakter

Pembinaan karakter pada anak dapat dilakukan melalui Al-Fatihah dengan membina sikap dan prilaku anak. Sehingga dalam keseharianya tidak sembarang mengeluarkan bahasa dan berprilaku karena anak yang dibina akan memikir dulu ketia ia berucap dan berprilaku.

Jadi karakter adalah sikap sopan santun. Sedangkan menurut ahli psikologi, karakter merupakan prilaku yang cenderung baik dan buruk sehingga kebiasaan yang mengarahkan kepada prilaku anak. Kendati demikian, karakter anak tergantung lingkungan keluarga, masyarakat, jika lingkunganya baik maka baik pula karakter anak. Anak membutuhkan orang tua, keluarga dan masyarakat untuk membina bersama membangun karakter anak menjadi anak yang berkarakter sopan santun serta mampu membangun karismanya dalam kehidupanya sehari-hari. ${ }^{9}$

Untaian di atas, bahwa karakter merupakan sikap sopan santun dalam diri anak dan mampu mengimplementasikan karakter tersebut dalam kehidupanya serta mampu memilih dan memilah teman bergaul mana yang baik dan mana yang buruk. Sehingga anak mempu menjaga adab-adabnya dalam bergaul..

Sesuai firman Allah SWT yang artinya:

"Sesungguhnya telah ada pada (diri) Rasulullah itu suri teladan yang baik bagimu (yaitu) bagi orang yang mengharap (rahmat) Allah dan (kedatangan) hari kiamat dan dia banyak menyebut Allah”. (QS. Al-Ahzab: 21).

${ }^{8}$ Zakiah Daradjat, dkk, Dasar-dasar Agama Islam, (Cet. VIII ; Jakarta : PN. Bulan Bintang, 1993), 302.

${ }^{9}$ Sjarkawi, Pembentukan Kepribadian Anak; Peran Moral, Intelektual, Emosional Dan Sosial Sebagai Wujud Membangun Jati diri (Jakarta: PT Bumi Aksara, 2006), 11. 
Dari ayat di atas, bahwa sudah ada pada diri Rasulullah Muhammad SAW memiliki sikap dan prilaku terpuji sebagai contoh uswatun hasanah oleh umatnya. Prilaku terpuji dijaga dan dirawat dari hal tercela dan terus ditanamkan kedalam jiwa sehingga nantinya dapat mencerminkan karakter yang terpuji (mulia). Pembinaan karakter adalah bimbingan, proses, dalam melatih diri bersikap dan berprilaku sopan santun yang diberikan kepada anak untuk dapat memperoleh hasil yang lebih baik yakni karakter mulia.. ${ }^{10}$

Jadi pembinaaan karakter merupakan model upaya untuk memberikan pembinaan nilainilai karakter dan diperlukan didikan serta bimbingan pada anak untuk dapat lebih meningkatkan unsur-unsur kebaikan dalam dirinya baik terhadap diri sendiri maupun orang lain. Pembinaan dapat dilakukan melalui surah Al-Fatihah. Pembinaan tidak hanya sekali akan tetapi dilakukan secara intens.

Pembinaan Karakter merupakan suatu tindakan untuk mendidik, membina karakter anak serta perilaku anak dapat terbiasa mengenal, memahami, menghayati sifat-sifat baik. Pembinaan karakter ini perlu ditanamkan sejak dini kepada seseorang, dan pembinaan dilakukan melalui Al-Qur,an surah Al-Fatihah. Anak dapat dikatakan berkarakter jika telah berhasil menjaga adab sopan santunya dan mampu menyerap nilai dan keyakinan yang dikehendaki masyarakat serta digunakan sebagai kekuatan moral dalam hidupnya. Demikian juga, seorang pendidik dikatakan berkarakter jika ia memiliki nilai dan keyakinan yang dilandasi hakikat dan tujuan pendidikan serta digunakan sebagai kekuatan moral dalam menjalankan tugasnya sebagai pendidik. ${ }^{11}$

Kendati demikian, pembinaan karakter yakni anak memiliki sikap sopan santun dan dapat ditinjau dari prilaku, tabiat, sifat serta nilai adabnya, seperti nilai agama, integritas, mandiri, gotong royong. yang harus melekat pada anak.

Kendati demikian, pembinaan pendidikan karakter anak memiliki fungsi yakni:

a. Pembinaan karakter, yaitu meningkatkan moral anak yang sudah hilang dan punah serta menghidupkan kembali moralnya

b. Perbaikan, yaitu memperbaiki moral anak yang sudah rusak dan memperdalam nilai-nilai agama

${ }^{10}$ Ahmad D. Marimba, Pengantar Filsafat Pendidikan Islam, (Cet. VIII ; Bandung : PT. Al-Ma'arif, 1989), 75.

${ }^{11}$ Hidayatullah, Pendidikan Karakter Membangun Peradaban Bangsa. (Surakarta: Yuma Pustaka, 2010), 13. 
Kendati demikian, pendidikan karakter anak dapat dilakukan berbagaia macam binaan salah satunya melalui Al-Qur'an surah Al-Fatihah serta bahu membahu mendidik anak. Pembinaan karakter dapat mengembalikan nilai karakter mulia anak dimata masyarakat, untuk itu orang tua memberikan sarana penguatan karakter pada anak yakni:

a. Anak akan disegani di mata masyarakat

b. Anak dapat ternilai dimata masyarakat

c. Anak akan disenangi orang dalam pergaulan

Yang mempengaruhi kelemahan karakter anak yakni:

a. Kelemahan agama

b. Kelemahan ekonomi

c. Kelemahan ilmu

Dari ketiga hal tersebut di atas dapat mempengaruhi pendidikan karakter anak, bukan itu saja selain lemah ilmu, lemah agama, dan lemah ekonomi anak juga akan menjadi fitnah dunia dan fitnah di akhirat dan bahkan akan menjadi musuh bagi orang tuanya. Oleh karena itu, perlu berhati-hati dalam membina anak, mendidik serta membimbing ke karakter yang mulia. Sehingga nantinya tidak dapat menyebabkan penyesalan bagi orang tuanya dikemudian hari.

1. Anak bisa menjadi fitnah

Sesuai firman Allah SWT yang artinya:

"Dan ketahuilah bahwa hartamu dan anak-anakmu itu hanyalah sebagai cobaan dan sesungguhnya di sisi Allah SWT disediakan pahala yang besar. (QS. Al-Anfal:28).

2. Anak menjadi musuh

Kemudian pada ayat lain Allah SWT berfirman yang artinya:

"Wahai orang-orang yang beriman, Sesungguhnya di antara isteri-isterimu dan anakanakmu ada yang menjadi musuh bagimu, maka berhati-hatilah kamu terhadap mereka dan jika kamu memaafkan dan kamu santuni serta ampuni (mereka), Maka sungguh, Allah Maha Pengampun lagi Maha Penyayang”. (QS. At-Taghabun: 14).

Dari ayat di atas, bahwa jagalah anak dan istri kejalan yang benar, bina anak dengan ucapan dan perbuatan yang baik, sehingga anak dan istri tidak akan menjadi musuh di dunia maupun di akhirat.

3. Anak bisa menjadi pendamaian hati dan pelipur lara

Allah SWT berfirman yang artinya:

"Dijadikan terasa indah dalam pandangan manusia cinta terhadap apa yang diinginkan, berupa perempuan-perempuan, anak-anak, harta benda yang bertumpuk dalam bentuk emas dan perak, kuda pilihan, hewan ternak, dan sawah ladang. Itulah kesenangan hidup di dunia, dan di sisi Allah-lah tempat kembali yang baik". (QS. Ali Imran: 14). 
Dari ayat di atas, bahwa binatang ternak di sini yakni hewan yang termasuk jenis unta, lembu, kambing dan biri-biri.

4. Anak menjadi bisa menjadi penyelamat dunia dan akhirat (sholeh dan sholeha)

Sesuai firman Allah SWT yang artinya:

"Harta dan anak-anak adalah perhiasan kehidupan dunia tetapi amal kebajikan yang terus-menerlus adalah lebih baik pahalanya di sisi Tuhanmu serta lebih baik untuk menjadi harapan".(QS. Al-Kahfi: 46).

Dari penjelasan ayat di atas, bahwa anak akan menjadi penolong untuk orang tuanya baik di dunia dan akhirat, jika orang tua membina, mendidik, membimbing anak pada karakter mulia yang sesuai Al-Qur'an dan Hadits.

\section{METODE PENELITIAN}

Peneliti akan menitik beratkan pada olahan data secara kualitatif. pendekatan kualitatif merupakan suatu paradigma penelitian untuk mendeskripsikan suatu peristiwa. ${ }^{12}$ Adapun proses penyimpulan datanya bertumpu pada kajian dan studi literatur, metodologis, serta menganalisis fenomena.

\section{METODE ANALISIS DATA}

Adapun metode analisis data yang di tempuh yakni:

1. Metode tafsir tahlili ini cara penafsiranya menggunakan logika sehingga pembahasanya melahirkan pembahasan yang sangat luas dalam menelusuri berbagai macam kandungan Al-Qur'an dari semua aspek. Baik dari kandungan ayat AlFatihah, asbabun nuzul serta munasabah. ${ }^{13}$

2. Metode Komparasi ini cara penafsiranya dengan membandingkan antara penelitian yang dulu dan yang sekarang serta letak perbedaan mengungkapkan kandungan surah Al-Fatihah sebagai petunjuk pembinaan nilai-nilai karakter anak. ${ }^{14}$

3. Metode interpretasi ini cara penafsiranya menggunakan teks yang terdapat pada AlQur'an Surah Al-Fatihah sebagai sarana atau alat dalam menjelaskan nilai-nilai karakter yang terdapat pada surah Al-Fatihah. ${ }^{15}$

\footnotetext{
${ }^{12}$ Djam'an Satori, Metodologi Penelitian Kualitatif, (CV. Alfa Beta, 2014 ), 236.

${ }^{13}$ Al-Farmawy, Abd al-Havy, Metode Tafsir Maudhu'y Suatu Pengantar Terjema Surya A. Jarman (Bandung: PT Raja Grafindo Persada, 1996), 12.

${ }^{14}$ Surachmad, Pengantar Penelitian Ilmiah, (Dasar-Dasar, Metode Teknik): Bandung: Tarsito, 2007, 119.

${ }^{15}$ Ahmad Chainus Zubair and Anton Bakker, Metodologi Penelitian Filsafat (Yogyakarta: Kanisius, 1994), 74.
} 
Berdasarkan paparan tersebut peneliti menggunakan metode kualitatif dengan menggunakan tiga analisis dalam penelitian untuk mengkaji "Pembinaan Nilai-Nilai Karakter anak Berbasis Ai-Qur'an Surah Al-Fatihah Sebagai Penguatan Karakter”.

\section{HASIL PENELITIAN DAN PEMBAHASAN}

\section{Pembinaan Nilai-nilai Karakter berbasis Al-Fatihah}

Pembinaan Karakter berbasis Al-Fatihah pada diri anak dan dikuatkan kembali melalui pembinaan, bimbingan serta mendidik yakni;

\section{Pembinaan keagamaan}
a. Penanaman nilai-nilai agama (religius)
b. Pembinaan tingkah laku (Akhlak)
c. Pembinaan keyakinan (Akidah)
d. Pembinaan ritual Ibadah
e. Pembinaan anak dengan masyarakat (Muamalah Duniawiyah).

\section{Pembinaan jiwa sosial anak}
a. Pembinaan jiwa gotong royong
b. Pembinaan jiwa kepedulian
c. Pembinaan kebersamaan
d. PemLbinaan membangun ketakwaan dan ketaatan kepada Allah SWT
e. Pembinaan jiwa persaudaraan

Dengan demikian, maka dapat dipahami bahwa pembinaan kakrakter berbasis Al-Fatihah sangat penting dengan melakukan pembinaan serta memperkuat nilai-nilai karakter anak, pembinaan tersebut dilakukan dengan terus-menerus demi terwujudnya adab sopan santun.

\section{Nilai-nilai karakter yang terdapat pada surah Al-Fatihah mulai ayat 1 hingga ayat 7 yakni:}

\section{Nilai Religius}

1. Mengajarkan pada anak untuk berprilaku jujur dalam berbicara dan bersikap

2. Mengajarkan pada anak untuk saling menyayangi satu sama lain

3. Mengajarkan pada anak untuk Hablumminannas Wahablumminallah

4. Mengajarkan pada anak untuk bertaqwa, taat dan beriman kepada Allah SWT

5. Mengajarkan pada anak untuk bersikap toleransi terhadap sesama

6. Mengajarkan pada anak untuk mengamalkan surah Al-Fatihah

\section{Integritas}

1. Mengajarkan pada anak untuk berani berucap, berbuat kebaikan

2. Mengajarkan pada anak untuk berani sikap jujur

3. Mengajarkan anak untuk berani berkomitmen dan tanggung jawab 
4. Mengajarkan anak untuk berani bertanggung jawab

5. Mengajarkan anak untuk berani pada jalan yang benar

6. Mengajarkan anak untuk bersyukur

\section{Nilai Nasionalis}

1. Mengajarkan pada anak untuk menghormati guru dan dosen

2. Mengajarkan pada anak untuk menghormati bendera

3. Mengajarkan pada anak untuk menghormati jasa para pahlawan dengan menghadiahkan doa surah Al-Fatihah

4. Mengajarkan pada anak untuk saling menjaga bineka tunggal ika

5. Mengajarkan pada anak untuk rela berkorban pada Bangsa dan Negara Indonesia

6. Mengajarkan pada anak untuk rutin donor darah pada yang membutuhkan

\section{Nilai Mandiri}

1. Mengajarkan pada anak untuk berani sikap patriotisme

2. Mengajarkan pada anak untuk saling menolong terhadap sesama

3. Mengajarkan pada anak untuk bekerja dengan amanah

4. Mengajarkan pada anak untuk berani literasi

5. Mengajarkan anak memiliki skiil

6. Mengajarkan anak mengutamakan prilaku baik dan benar

\section{Nilai Gotong Royong}

1. Mengajarkan pada anak untuk menjenguk tetangga yang sakit

2. Mengajarkan pada anak untuk membersihkan musola dan masjid

3. Mengajarkan pada anak untuk cinta damai

4. Mengajarkan pada anak untuk menjaga dan membersihkan tempat pemakan umum

5. Mengajarkan pada anak untuk gotong royong membangun masjid

6. Mengajarkan pada anak untuk berta'jiyah pada acara 7 hari dan 44 hari

\section{KESIMPULAN}

Pembinaan nilai karakter pada anak berbasis Al-Fatihah diperlukan melalui pembinaan dasar yang dilakukan pembinaan Religius, jiwa sosial anak serta penguatan nilai-nilai karakter, hal ini dimulai dari ayat pertama Surah Al-Fatihah hingga akhir mengandung adab sopan santun serta nilai yang mendidik memanusiakan manusia yakni: agama, Integritas, Nasionalis dan Mandiri serta Gotong Royong. Apabila dilakukan pembinaan karakter berbasis Al-Fatihah tersebut, maka akan melahirkan anak-anak yang beradab, berkarakter mulia baik terhadap dirinya sendiri, orang lain, keluarga maupun pada pelaksanakan ajaran agamanya. 


\section{DAFTAR PUSTAKA}

Anas Salahudin, Irwanto Alkrienciehie, Pendidikan Karakter, Pendidikan Berbasis Agama dan Budaya Bangsa, Bandung Pustaka Setia, 2013.

Ahmad D. Marimba, Pengantar Filsafat Pendidikan Islam, (Cet. VIII ; Bandung : PT. AlMa'arif, 1989).

Abd al-Havy Al-Farmawy, Metode Tafsir Maudhu'y Suatu Pengantar Terjema Surya A. Jarman (Bandung: PT Raja Grafindo Persada, 1996).

Anton Bakker and Ahmad Chainus Zubair, Metodologi Penelitian Filsafat (Yogyakarta: Kanisius, 1994).

Darwis Abu Ubaidah, Tafsir Al-Asas (Jakarta: Pustaka al-Kautsar, 2012).

Djam'an Satori, Metodologi Penelitian Kualitatif, (CV. Alfa Beta, 2014 ).

Doni Koesoema A, Pendidikan Karakter: Strategi Mendidik Anak di Zaman Global. Jakarta: Grasindo. Cet. I. 2007.

Echolis, John M. Dan Hassan Shadily, Kamus Inggris Indonesia.Jakarta: Gramedia. Cet. X, 1987.

Hidayatullah, Pendidikan Karakter Membangun Peradaban Bangsa. (Surakarta: Yuma Pustaka, 2010).

Kevin Ryan dan Karen E. Bohlin, Buliding Character in Schools: Pratical Ways to Bring Moral Instruction to Life. San Francisco: Jossey Bass, 1999.

Lickona, Thomas, Educating For Character: How Our School Can Teach Respect and Responsibility. Now York, Toronto, London, Sydney, Aucland: Bantam books, 1991.

Nana Sudjana, dan Ibrahim, Penelitian dan Penelitian Kualitatif, (Bandung : Sinar Baru, 1989).

Pusat Bahasa Departemen Pendidikan Nasional, Kamus Bahasa Indonesia. Jakarta: Pusat Bahasa. Cet. I, 2008.

Sugiyono, Metode Penelitian Pendidikan Pendekatan Kuantitatif, Kualitatif dan R\&D, (Bandung: Alfabeta, 2009).

Suparlan Suryapratondo, Ilmu Jiwa Kepribadian, (Jakarta : PT. Paryu Berkah, 1984).

Surachmad, Winarto. Pengantar Penelitian Ilmiah, Dasar-Dasar, Metode Teknik. Bandung: Tarsito, 2007.

Suparlan Suryapratondo, Ilmu Jiwa Kepribadian, (Jakarta : PT. Paryu Berkah, 1984).

T.M. Hasby Ash Shiddiqy, Sejarah dan Pengantar Ilmu Tauhid/Kalam, (Cet. VI ; Jakarta : PT. Bulan Bintang, 1992).

Zakiah Daradjat, dkk, Dasar-dasar Agama Islam, (Cet. VIII ; Jakarta : PN. Bulan Bintang, 1993). 